\title{
EFFECT OF SOME GROWTH PROMOTERS ON PERFORMANCE OF WHITE AND BROWN BOVANS LAYERS
}

\author{
Bahnas, M. S.; Mousa, M. A. and Khalifa, M. A. \\ Poult. Prod. Dept., Fac. Agric., Fayoum Univ., Egypt
}

\section{ABSTRACT:}

A total number of 570 Bovans hens was used in this experiment. Hens were classified into two equal strains (White and Brown) of 285 hens each and were divided into 3 treatments, each of 95 hens. One experimental corn- soybean meal diets was formulated. The basal diet contained $19.0 \% \mathrm{CP}$ and $2800 \mathrm{Kcal} \mathrm{ME} / \mathrm{Kg}$ diet was fed during the laying period. Two types of probiotics were supplemented to the diet (2 $\mathrm{kg} / \mathrm{ton}$ ) to study their effects on productive performance commercial laying hens compared to the control diet (without growth promoters):1Choong Ang Yeast Culture (CYC-100) is a unique live yeast culture product (saccharomyces cerevisiae $1.510 \times 10^{11} \mathrm{CFU} / \mathrm{kg}$ ) and 2- More Yeast (MY) is a unique dead yeast culture (saccharomyces cerevisiae). Hens in all treatments were kept under a similar management system.

The obtained results were summarized as follows:

- It can be concluded that Brown Bovans had significantly better feed conversion (FC) and economic of efficiency than White Bovans being $5.60 \mathrm{~g}$ feed/ $\mathrm{g}$ egg mass and $0.747 \mathrm{vs} 7.00 \mathrm{~g}$ feed/ $\mathrm{g}$ egg mass and 0.723 . The MY treatment had higher economical efficiency of 0.777 than other the treatments.

- The White Bovans had significantly higher egg production \% with lower egg weight (EW) than the Brown Bovans being $72.81 \%$ and $54.66 \mathrm{~g}$ vs $68.80 \%$ and $55.81 \mathrm{~g}$, respectively. Hens fed the diets supplemented with CYC-100 and MY had higher egg production\%, EW and egg mass (EM) than those fed the control diet. The highest egg production\%, EW and EM were shown during the period from 29-32 weeks of age being $90.65 \%, 60.42$ and $4922.05 \mathrm{~g}$, respectively.

- White Bovans had significantly higher haematocrit value (Ht \%) and haemoglobin value $(\mathrm{g} / \mathrm{dl})$ than the Brown Bovans $(25.76 \%$ and $9.64 \mathrm{~g} / 100 \mathrm{ml}$ vs $24.30 \%$ and $9.05 \mathrm{~g} / 100 \mathrm{ml}, \mathrm{P} \leq 0.05$ ). Hens fed the MY supplemented diets had lower $\mathrm{Ht} \%$ and $\mathrm{Hb}$ of $24.19 \%$ and $8.87 \mathrm{~g} / 100 \mathrm{ml}$ than the other treatments.

- Diets supplemented with both CYC-100 and MY\ had lower cholesterol content than those fed the control diet. It can be seen that as birds advanced in age and production, both $\mathrm{Ht} \%$ and $\mathrm{Hb}$ gradually increased. The period from 21-24 weeks of age had the lowest $\mathrm{Ht}, \mathrm{Hb}$ and cholesterol estimates of $21.55 \% 8.13 \mathrm{~g} / 100 \mathrm{ml}$ and $149.05 \mathrm{mg} / \mathrm{dl}$.

Key words: Probiotics, layer performance, White and Brown Bovans hens.

Fayoum J. Agric. Res. \& Dev., Vol.22, No.2, July, 2008 
INTRODUCTION

Since the continued use of subtherapeutic levels of antibiotics in animal feeds may result in the presence of antibiotics residues in animal products and the development of drug- resistant micro- organisms in humans. Therefore, the use of probiotics (direct- fed microbials) as a substitute for antibiotics in poultry production has become an area of great interest. The use of antibiotics as routine feed additives has been banned in some countries because of public concern over possible antibiotic residual effects and the development of drug-resistant bacteria. Probiotics have been introduced as an alternative to antibiotics; however their effects on poultry production are not consistent resulting in uncertainties and scepticism for development of the products. Some of the proposed modes of action of probiotics in poultry include (1) maintaining a beneficial microbial population in the alimentary tract (Fuller, 1989) (2) improving feed intake and digestion (Nahashon et al., 1992 and 1993), and (3) altering bacterial metabolism (Jin et al., 1997). Savage et al. (1986) found that lactobacillus stimulate intestinal villi which extracts nutrients from feed stuffs during digestion. All these effects may accelerate the absorption of most nutrients and this may account for the improvement in feed conversion. Also, Fuller (1997) reported that improvement in feed conversion by probiotics may be due to the balance of microbial population created in the intestinal tract and to the role of Lactobacillus in preventing the harmful bacteria which invade population in the digestive tract of the chickens. Similar results were obtained by Nahashon et al. (1994a, b and 1996a, b), Mohan et al. (1995) and Tortuero and Fernandez (1995), Balevi et al. (2001).

Several investigators reported that supplementation of layer diets with probiotics significantly improved feed conversion, hen-day egg production \%, egg weight and egg mass (Abd El- Rahman, 1993, Hamid et al., 1994, Tortuero and Fernandez, 1995, Abdulrahim et al., 1996), Haddadin et al., 1996, Ghazalah and Ibrahim, 1998, Panda et al., 2000, Kucukersan et al., 2002, Osman, 2003, Siam et al., 2004 and Yousefi and Karoodi 2007). Kaya et al. (2003) used probiotic (Yucca Schidigera) in laying quails diet at 9-14 weeks of age and observed no effect on haemoglobin concentration and packed cell volume (PCV). However, Katz and Demain (1977) and Panda et al. (2003) indicated that the reduction in cholesterol concentration was due to the inhibition of culture within the intestine. The reduction of plasma cholesterol was explained using rats as experimental animals by Rao et al. (1981) and Nelson and Gilliand (1984). This reduction in absorption and/or synthesis of cholesterol is happened in the gastrointestinal tract. Furthermore, Mohan et al. (1995) reported that lactobacillus acidophilus reduces cholesterol in the blood by deconjugating bile salt in the intestine thereby preventing them from acting as precursor in cholesterol synthesis and caused a reduction in the serum cholesterol. The objective of the present study was to measure the effect of two growth promoters, Choong Ang Yeast culture (CYC-100) and More Yeast (MY) on feed intake, feed conversion, egg production traits, some blood parameters and economical efficiencies from 21-32 weeks of age in White and Brown Bovans layers.

Fayoum J. Agric. Res. \& Dev., Vol.22, No.2, July, 2008 
EFFECT OF SOME GROWTH PROMOTERS ON PERFORMANCE ... 248 MATERIALS AND METHODS

The experimental work of the present study was carried out at the farms of Cooperative El- Ekhlass Society for Development of Animal and Poultry Wealth, Giza, Governorate, Egypt. The chemical analyses of samples were performed in the laborites of the Poultry Production Department, Faculty of Agriculture, Fayoum University. Total number of 570 Bovans hens was used in this experiment. Hens were randomly classified into two equal strains (White and Brown) of 285 hens each and were divided into 3 treatments, each of 95 hens. One experimental corn- soybean meal diets was formulated. The basal diet contained $19.0 \% \mathrm{CP}$ and $2800 \mathrm{Kcal} \mathrm{ME} / \mathrm{Kg}$ diet was fed during the laying period. Two types of probiotics were supplemented to the diet $(2 \mathrm{~kg} / \mathrm{ton})$ to study their effects on productive performance commercial laying hen compared to the control diet (without growth promoters): 1- Choong Ang Yeast Culture (CYC100 ) is a unique live yeast culture product (saccharomyces cerevisiae $1.510 \times 10^{11}$ $\mathrm{CFU} / \mathrm{kg}$ ) and 2- More Yeast (MY) is a dead yeast culture of the same strain. Hens in all treatments were kept under a similar management system. The experimental diet was mixed each week to insure that a viable microbial culture is present during the experimental period (from 21-32 weeks of age). Experimental mash diet and fresh clean water were offered ad-libitum all over the experimental period. Light schedule was held artificially according to the system of brooding period and reached 17 hours daily in the laying period. Electerical and gas heaters were used to provide the chicks with heat needed for brooding.

The following criteria were measured and/or calculated:

Feed intake (FI): Residual feed was weekly collected, weighed and subtracted from the offered one to obtain FI on a group basis for each treatment.

Feed conversion (FC): It was calculated using the following equation: Grams feed intake/grams of egg mass.

Egg production \%: It was calculated as follows: Daily egg number/ Birds numberx 100

Egg weight (EW): It was obtained on a hen- day basis from 21 up to 32 weeks of age by dividing the total egg weights by its total number to obtain the average.

Egg mass (EM): It was calculated by multiplying egg number by the average egg weight.

Economical efficiency: The economical efficiency was calculated from the input- output analysis based upon the difference in egg mass and feeding cost (Heady and Jensen 1954).

\section{Haematological Parameters:}

Blood samples, about $5 \mathrm{ml}$ were obtained in heparinized test tubes from the brachial vein at 24, 28 and 32 weeks of age from 6 birds in each group. Blood picture was measured immediately and plasma was separated by centrifugation for 15 minutes at a speed of $3000 \mathrm{rpm}$ and kept frozen at $-20^{\circ} \mathrm{C}$ until blood analysis. Haematocrit value $(\mathrm{Ht} \%)$ was determined according to Wintrobe method. Blood hemoglobin concentration $(\mathrm{g} / 100 \mathrm{ml})$ was determined according to Makaren (1974). Plasma cholesterol was determined according to Richmond (1973).

Fayoum J. Agric. Res. \& Dev., Vol.22, No.2, July, 2008 
Statistical Analysis:

Analysis of variance was performed using the General Linear Model (GLM) procedure of statistical analysis system (SAS, 1982) according to Steel and Torrie (1980) adopting the following model for laying performance traits:

$$
Y \mathbf{i j k l}=\boldsymbol{\mu}+\mathbf{T}_{\mathrm{i}}+\mathrm{S}_{\mathrm{j}}+\mathbf{P}_{\mathrm{k}}+\mathbf{T S}_{\mathrm{ij}}+\mathbf{e}_{\mathrm{ijkl}}
$$

$\boldsymbol{\mu}=$ Overall mean, $\mathbf{T}_{\mathbf{i}}=$ Effect of treatment, $\mathbf{S}_{\mathbf{j}}=$ Effect of strain, $\mathbf{P}_{\mathbf{k}}=$ Effect of period, $\mathbf{T S}_{\mathbf{i j}}=$ Treatment $\mathrm{x}$ Strain interaction, $\mathbf{e}_{\mathbf{i j k}}=$ Random error term for layer performance traits. Variable means for treatments indicating significant differences in the ANOVA were tested using Dumcan's Multiple Range Test (Duncan, 1955).

Table 1. Composition of the experimental basal diet used from 21 up to 32 weeks of age.

\begin{tabular}{|l|c|}
\hline \multicolumn{1}{|c|}{ Ingredients } & \% \\
\hline Ground yellow corn & 55.00 \\
\hline Soybean meal (44\% cp) & 31.60 \\
\hline Ground lime stone & 8.50 \\
\hline Vegetable oil & 3.00 \\
\hline Bone meal & 1.00 \\
\hline Sodium chloride & 0.30 \\
\hline Vit and Min- Mix $*$ & 0.30 \\
\hline Sodium bicarbomate & 0.10 \\
\hline DL- Methioine & 0.10 \\
\hline Choline Chloride & 0.10 \\
\hline Calculated analysis: & 100 \\
\hline Crude protein & 18.80 \\
\hline Crude fiber & 3.52 \\
\hline Crude fat & 5.56 \\
\hline Ash & 10.81 \\
\hline Ca. & 3.62 \\
\hline P, Total & 0.48 \\
\hline P, avail & 0.26 \\
\hline Met. & 0.41 \\
\hline Met. +Cyst. & 0.686 \\
\hline Lys. & 1.06 \\
\hline ME, Kcal/ Kg & 2820 \\
\hline
\end{tabular}

* The vitamin and mineral mixture (Rovimix layer $\&$ broiler breeder Roche) was added as 3 $\mathrm{kg}$ per ton of diet and supplied the following (as $\mathrm{mg}$ or I.U. per $\mathrm{kg}$ of diet) vit A 12500,vit D3 2500 I.U., vit E 40mg, vit K3 4mg Vit. B1 2mg, vit B2 10mg, vit B6 5mg vit, B12 0.02mg, Niacin 40mg, Biotin $0.15 \mathrm{mg}$ pantothenic acid $12 \mathrm{mg}$ folic acid $1.5 \mathrm{mg}$, choline chloride 700mg, Mn 100mg, Cu 10mg, Se 0.2mg, Fe 40mg, Zn 80 mg, I 0.5mg and Co 0.25mg.

Fayoum J. Agric. Res. \& Dev., Vol.22, No.2, July, 2008 
EFFECT OF SOME GROWTH PROMOTERS ON PERFORMANCE ... 250 RESULTS AND DISCUSSION

Concerning strain effect, Brown Bovans had significantly better FC and economical efficiency than White Bovans being $5.60 \mathrm{~g}$ feed/ $\mathrm{g}$ egg mass and $0.747 \mathrm{vs} 7.00 \mathrm{~g}$ feed $/ \mathrm{g}$ egg mass and 0.723 . However, strain insignificantly affected FI, regardless of treatment or period effects as shown in Table 2.

Growth promoters resulted in an increase in FI of hens fed the diets supplemented by either CYC-100 or MY than those fed the control diet. The group fed the CYC-100 had significantly higher FI and poorer FC and economical efficiency than those fed the control diet being $(108.20 \mathrm{~g}, 7.18 \mathrm{~g}$ feed/g egg mass and 0.685, respectively. However, the MY treatment had a higher economical efficiency of 0.777 than other treatments (Table 2).

Table 2. Effects of growth promoters (Ang Yeast Culture CYC-100 and More Yeast MY), strain and period on feed traits and economic efficiency $(\mathrm{M} \pm \mathrm{SE})$.

\begin{tabular}{|c|c|c|c|}
\hline Main effects & $\begin{array}{l}\text { Feed intake, } \\
\text { g/bird/day }\end{array}$ & $\begin{array}{l}\text { Feed conversion, } \\
\mathrm{g} \text { feed/g egg mass }\end{array}$ & $\begin{array}{l}\text { Economic } \\
\text { efficiency }\end{array}$ \\
\hline \multicolumn{4}{|l|}{ Strain effect: } \\
\hline White Bovans & $107.01 \pm 0.77 a$ & $7.00 \pm 0.91 a$ & 0.723 \\
\hline Brown Bovans & $105.62 \pm 0.77 a$ & $5.60 \pm 0.90 \mathrm{~b}$ & 0.747 \\
\hline \multicolumn{4}{|l|}{ Treatment effect: } \\
\hline Control & $104.32 \pm 0.95 b$ & $6.17 \pm 1.11 a$ & 0.750 \\
\hline CYC-100 & $108.20 \pm 0.94 a$ & $7.18 \pm 1.11 b$ & 0.685 \\
\hline MY & $106.43 \pm 0.94 a b$ & $6.03 \pm 1.12 a$ & 0.777 \\
\hline \multicolumn{4}{|l|}{ Period effect: } \\
\hline 21-24wks & $95.22 \pm 0.95 b$ & $15.14 \pm 1.12 a$ & \\
\hline 25-28wks & $110.83 \pm 0.94 a$ & $2.22 \pm 1.11 b$ & \\
\hline 29-32wks & $112.90 \pm 0.94 a$ & $2.02 \pm 1.11 \mathrm{c}$ & \\
\hline
\end{tabular}

a and b: Means having different superscripts within each column and each effect are significantly different $(\mathbf{P}<0.05)$.

Period of production significantly influenced either FI or FC $(\mathrm{P} \leq 0.05)$. Hens had the lowest FI of 95.22g during the period from 21-24 weeks of age, however those fed both growth promoters insignificantly differed. Hens had the best FC of $2.02 \mathrm{~g}$ feed/g egg mass during the period from 29-32weeks of age whereas the worst FC was $15.14 \mathrm{~g}$ feed/g egg mass during the early period of production from 21-24 weeks of age as shown in Table 2. These results were in full agreement with the findings reported by several authors (Tortuero and Fernandez, 1995, Siam et al., 2004 Nahashon et al., 1994 b, Mohan et al., 1995 and Haddadin et al., 1996) in laying hens and (Ghazalah and Ibrahim, 1998) with laying Japanese quails. They found that continuous lactobacillus acidophilus dosing lowered the $\mathrm{PH}$ in the crop, cecum and rectum. They also added that the particular strain of lactobacillus acidophilus was capable of competing with Ecoli in the gut. All these effects may cause an alternation in the absorption of most nutrients, and this may be accounted for the improved efficiency of feed utilization. Fuller (1997) explained this improvement in FC by probiotics may be due to the balance of

Fayoum J. Agric. Res. \& Dev., Vol.22, No.2, July, 2008 
microbial population created in the intestinal tract and to the role of lactobacillus in preventing the harmful bacteria which invade population in the digestive tract of the birds.

There were significant differences due to strain for both egg production\% and EW. The White Bovans had significantly higher egg production \% with lower EW than the Brown Bovans being $72.81 \%$ and $54.66 \mathrm{~g}$ vs $68.80 \%$ and $55.81 \mathrm{~g}$, respectively. However, strain insignificantly affected EW as shown in Table 3 .

Table 3. Effects of growth promoters (Ang Yeast Culture CYC-100 and More Yeast MY), strain and period on egg production traits $(\mathrm{M} \pm \mathrm{SE})$.

\begin{tabular}{|c|c|c|c|}
\hline Main effects & $\begin{array}{c}\text { Egg } \\
\text { production } \%\end{array}$ & Egg weight, $g$ & Egg mass, $g$ \\
\hline Strain effect: & & & \\
\hline White Bovans & $72.81 \pm 0.93 \mathrm{a}$ & $54.66 \pm 0.19 \mathrm{~b}$ & $3706.16 \pm 44.47 \mathrm{a}$ \\
\hline Brown Bovans & $68.80 \pm 0.27 \mathrm{~b}$ & $55.81 \pm 0.18 \mathrm{a}$ & $3769.78 \pm 44.19 \mathrm{a}$ \\
\hline Treatment effect: & & & \\
\hline Control & $68.38 \pm 1.13 \mathrm{~b}$ & $\mathbf{5 4 . 7 7} \pm 0.23 \mathrm{~b}$ & $\mathbf{3 6 4 0 . 4 7} \pm 54.29 \mathrm{~b}$ \\
\hline CYC-100 & $72.20 \pm 1.13 \mathrm{a}$ & $\mathbf{5 5 . 2 6} \pm 0.23 \mathrm{ab}$ & $3809.38 \pm 54.12 \mathrm{a}$ \\
\hline MY & $71.84 \pm 1.14 \mathrm{a}$ & $55.67 \pm 0.23 \mathrm{a}$ & $3764.06 \pm 54.47 \mathrm{a}$ \\
\hline Period effect: & & & \\
\hline $21-24 w k s$ & $36.13 \pm 1.15 \mathrm{c}$ & $48.74 \pm 0.23 \mathrm{c}$ & $1719.58 \pm 54.63 \mathrm{c}$ \\
\hline $25-28 w k s$ & $85.63 \pm 1.14 \mathrm{~b}$ & $56.56 \pm 0.23 \mathrm{~b}$ & $4572.28 \pm 45.12 \mathrm{~b}$ \\
\hline $29-32 w k s$ & $90.65 \pm 1.14 \mathrm{a}$ & $60.42 \pm 0.23 \mathrm{a}$ & $4922.05 \pm 54.12 \mathrm{a}$ \\
\hline
\end{tabular}

a and b: Means having different superscripts within each column and each effect are significantly different $(\mathbf{P}<0.05)$.

Results presented in Table 3 indicated that either treatment or period significantly influenced each of egg production $\%$, EW and $\mathrm{EM}(\mathrm{P} \leq 0.05)$. Hens fed the supplemented diets with CYC-100 and MY had higher egg production\%, EW and EM than those fed the control diet. Hens during the period from 21-24 weeks of age had the lowest egg production\%, EW and EM $(36.13 \%, 48.74$ and $1719.58 \mathrm{~g}$, respectively at $\mathrm{P} \leq 0.05)$. However, the highest egg production $\%$, EW and EM were shown during the period from 29-32 weeks of age being $90.65 \%$, 60.42 and $4922.05 \mathrm{~g}$, respectively as shown in Table 3 . It can be concluded that growth promoters (CYC-100 and MY) improved EP\% as compared with control. This finding was in full agreement with several authors (Miles et al., 1981, Ezzat et al., 1988, Haddadin et al., 1996, Panda et al., 2000, Kucukrsan et al., 2002 and Siam et al., 2004). Growth promoters MY slightly improved EW compared with the control. These results were in agreement with several authors (Abd El-Rahman 1993, Hamid et al., 1994, Panda et al., 2000, Osman, 2003 and Siam et al., 2004). Similar findings with respect to EM were reported by many authors (Ezzat et al., 1988, Nahashon et al. 1994b, Ghazalah and Ibrahim, 1998, Kucukersan et al., 2002 and Osman, 2003). Interactions had insignificant effects on the traits presented in Table 4.

Fayoum J. Agric. Res. \& Dev., Vol.22, No.2, July, 2008 
EFFECT OF SOME GROWTH PROMOTERS ON PERFORMANCE ... 252

Table 4. Effects of growth promoters (Ang Yeast Culture CYC-100 and More Yeast MY) and strain interaction on feed traits, layer performance traits and economic efficiency at different periods studied $(\mathrm{M} \pm \mathrm{SE})$.

\begin{tabular}{|c|c|c|c|c|c|c|}
\hline Period & \multicolumn{7}{|c|}{ White Bovans } & \multicolumn{3}{c|}{ Brown Bovans } \\
\hline & Control & CYC-100 & MY & Control & CYC-100 & MY \\
\hline \multicolumn{7}{|c|}{ Feed intake,g } \\
\hline $21-24 w k s$ & $\mathbf{8 8 . 6 4} \pm 2.36 b$ & $92.05 \pm 2.32 b$ & $94.37 \pm 2.32 b$ & $96.31 \pm 2.32 b$ & $99.79 \pm 2.32 b$ & $100.76 \pm 2.32 b$ \\
\hline $25-28 w k s$ & $109.47 \pm 2.32 a b$ & $111.25 \pm 2.32 a b$ & $113.81 \pm 2.32 a$ & $106.59 \pm 2.32 a$ & $113.11 \pm 2.32 a$ & $110.17 \pm 2.32 a$ \\
\hline $29-32 w k s$ & $118.27 \pm 2.32 a$ & $122.23 \pm 2.32 a$ & $113.01 \pm 2.32 a$ & $106.66 \pm 2.32 a$ & $110.79 \pm 2.32 a 106.44 \pm 2.32 a b$ \\
\hline \multicolumn{7}{|c|}{ Feed conversion, g feed/g egg mass } \\
\hline 21-24wks & $15.58 \pm 2.77 a$ & $22.39 \pm 2.72 a$ & $15.20 \pm 2.72 a$ & $12.78 \pm 2.72 a$ & $12.22 \pm 2.72 a$ & $12.69 \pm 2.72 a$ \\
\hline $25-28 w k s$ & $2.26 \pm 2.72 b$ & $2.18 \pm 2.72 b$ & $2.20 \pm 2.72 a b$ & $2.27 \pm 2.72 b$ & $2.28 \pm 2.72 a b$ & $2.16 \pm 2.72 a b$ \\
\hline $29-32 w k s$ & $2.13 \pm 2.72 b$ & $2.06 \pm 2.72 b$ & $1.98 \pm 2.72 b$ & $2.03 \pm 2.72 b$ & $1.98 \pm 2.72 b$ & $1.98 \pm 2.72 b$ \\
\hline \multicolumn{7}{|c|}{ Egg production \% } \\
\hline $21-24 w k s$ & $35.43 \pm 2.83 b$ & $36.17 \pm 2.78 b$ & $36.86 \pm 2.83 b$ & $32.68 \pm 2.78 b$ & $37.93 \pm 2.78 b$ & $37.63 \pm 2.78 b$ \\
\hline $25-28 w k s$ & $85.53 \pm 2.78 a b$ & $89.19 \pm 2.78 a b$ & $90.46 \pm 2.78 a$ & $79.52 \pm 2.78 a b 83.44 \pm 2.78 a b$ & $85.67 \pm 2.78 a$ \\
\hline $29-32 w k s$ & $92.80 \pm 2.78 a$ & $95.87 \pm 2.78 a$ & $92.92 \pm 2.78 a$ & $84.33 \pm 2.78 a$ & $90.60 \pm 2.78 a$ & $87.40 \pm 2.78 a$ \\
\hline \multicolumn{7}{|c|}{ Egg weight, g } \\
\hline $21-24 w k s$ & $48.23 \pm 0.56 b$ & $47.76 \pm 0.55 a$ & $49.48 \pm 0.57 b$ & $48.30 \pm 0.55 b$ & $49.63 \pm 0.55 b$ & $49.01 \pm 0.55 b$ \\
\hline $25-28 w k s$ & $55.30 \pm 0.55 a b$ & $55.00 \pm 0.55 a b$ & $56.13 \pm 0.55 a b$ & $56.64 \pm 0.55 a b$ & $58.14 \pm 0.55 a$ & $58.14 \pm 0.55 a$ \\
\hline $29-32 w k s$ & $59.07 \pm 0.55 a$ & $60.34 \pm 0.55 a$ & $60.66 \pm 0.55 a$ & $61.10 \pm 0.55 a$ & $60.70 \pm 0.55 a$ & $60.63 \pm 0.55 a$ \\
\hline \multicolumn{7}{|c|}{ Egg mass, g } \\
\hline 21-24wks & $1624 \pm 135 b$ & $1626 \pm 133 b$ & $1682 \pm 138 b$ & $1674 \pm 133 b$ & $1823 \pm 133 b$ & $1888 \pm 133 b$ \\
\hline $25-28 w k s$ & $4454 \pm 133 a$ & $4588 \pm 133 a b$ & $4595 \pm 133 a$ & $4498 \pm 133 a b$ & $4507 \pm 133 a b$ & $4791 \pm 133 a b$ \\
\hline $29-32 w k s$ & $4482 \pm 133 a$ & $5272 \pm 133 a$ & $4703 \pm 133 a$ & $4782 \pm 133 a$ & $5040 \pm 133 a$ & $4924 \pm 133 a$ \\
\hline \multicolumn{7}{|c|}{ Economic efficiency } \\
\hline $21-32 w k s$ & 0.74 & 0.66 & 0.77 & 0.76 & 0.71 & 0.77 \\
\hline
\end{tabular}

$a$ and b: Means having different superscripts within each row are significantly different $(P<0.05)$.

Results presented in Table 5 showed that White Bovans had significantly higher $\mathrm{Ht} \%$ and $\mathrm{Hb}$ than the Brown Bovans $(25.76 \%$ and $9.64 \mathrm{~g} / 100 \mathrm{ml}$ vs $24.30 \%$ and $9.05 \mathrm{~g} / 100 \mathrm{ml}, \mathrm{P} \leq 0.05$ ). However, no strain effect was shown for cholesterol concentration. Hens fed the MY supplemented diets had lower $\mathrm{Ht} \%$ and $\mathrm{Hb}$ of $24.19 \%$ and $8.87 \mathrm{~g} / 100 \mathrm{ml}$ than other the treatments. However, diets supplemented with both CYC-100 and MY had lower cholesterol contents than those fed the control diet as shown in Table 5. It can be seen that as birds advanced in age and production, both $\mathrm{Ht} \%$ and $\mathrm{Hb}$ gradually increased. The period from 21-24 weeks of age had the lowest $\mathrm{Ht}, \mathrm{Hb}$ and cholesterol estimates of $21.55 \% 8.13 \mathrm{~g} / 100 \mathrm{ml}$ and $149.05 \mathrm{mg} / \mathrm{dl}$ (Table 5). These results are in agreement with several authors (Abdulrahim et al., 1996, Kaya et al., 2003). The reduction in plasma cholesterol could be attributable to reduction in absorption and/or synthesis of cholesterol in the gastrointestinal tract by probiotics supplementation (Nelson and Gilliand, 1984). Furthermore, Mohan et al. (1995) stated that lactobacillus acidophilus reduces cholesterol in the blood by deconjugating bile salt in the intestine, thereby preventing them from

Fayoum J. Agric. Res. \& Dev., Vol.22, No.2, July, 2008 
acting as precursor in cholesterol synthesis and caused reducing in the plasma cholesterol. Strain $x$ treatment interaction effect on blood parameters traits at different periods are presented in Table 6 . The interaction effect was significant at all periods for $\mathrm{Ht} \%$ except the period from 29-32 weeks and was significant with all periods for Hb values. Also the interaction effect was significant for cholesterol concentration during the periods from 25-28 and 29-32 weeks of age (Table 6). It can be conclude that Brown Bovans hens had lower blood parameters traits than the white hens for all treatments and periods.

Table 5. Effects of growth promoters (Fang Yeast Culture CYC-100 and More Yeast MY), strain and period on blood parameters traits $(\mathrm{M} \pm \mathrm{SE})$.

\begin{tabular}{|c|c|c|c|}
\hline Main effects & $\begin{array}{c}\text { haematocrit } \\
\text { value\% }\end{array}$ & $\begin{array}{c}\text { Haemoglobin } \\
\text { value }(\mathrm{g} / 100 \mathrm{ml})\end{array}$ & $\begin{array}{c}\text { Cholesterol, } \\
\text { mg/dl }\end{array}$ \\
\hline Strain effect: & & & \\
\hline White Bovans & $25.76 \pm 0.48 \mathrm{a}$ & $9.64 \pm 0.19 \mathrm{a}$ & $174.54 \pm 2.96 \mathrm{a}$ \\
\hline Brown Bovans & $24.30 \pm 0.47 \mathrm{~b}$ & $9.05 \pm 0.18 \mathrm{~b}$ & $169.77 \pm 2.96 \mathrm{a}$ \\
\hline Treatment effect: & & & \\
\hline Control & $26.04 \pm 0.63 \mathrm{a}$ & $9.49 \pm 0.24 \mathrm{ab}$ & $175.35 \pm 3.63 \mathrm{a}$ \\
\hline CYC-100 & $24.87 \pm 0.56 \mathrm{ab}$ & $9.67 \pm 0.22 \mathrm{a}$ & $168.19 \pm 3.63 \mathrm{~b}$ \\
\hline MY & $24.19 \pm 0.56 \mathrm{~b}$ & $\mathbf{8 . 8 7} \pm 0.22 \mathrm{~b}$ & $172.92 \pm 3.62 \mathrm{ab}$ \\
\hline Period effect: & & & \\
\hline $21-24 w k s$ & $21.55 \pm 0.58 \mathrm{~b}$ & $\mathbf{8 . 1 3} \pm 0.23 \mathrm{~b}$ & $149.05 \pm 3.62 \mathrm{c}$ \\
\hline $25-28 w k s$ & $26.02 \pm 0.56 \mathrm{a}$ & $9.90 \pm 0.22 \mathrm{a}$ & $192.30 \pm 3.62 \mathrm{a}$ \\
\hline $29-32 w k s$ & $27.52 \pm 0.60 \mathrm{a}$ & $10.00 \pm 0.24 \mathrm{a}$ & $175.11 \pm 3.62 \mathrm{~b}$ \\
\hline
\end{tabular}

a and b: Means having different superscripts within each column and each effect are significantly different $(\mathbf{P}<0.05)$.

Table 6. Effects of growth promoters (Ang Yeast Culture CYC-100 and More Yeast MY) and strain interaction on blood parameters traits at different periods studied $(\mathrm{M} \pm \mathrm{SE})$.

\begin{tabular}{|c|c|c|c|c|c|c|}
\hline Period & \multicolumn{3}{|c|}{ White Bovans } & \multicolumn{3}{c|}{ Brown Bovans } \\
\hline & Control & CYC-100 & MY & Control & CYC-100 & MY \\
\hline \multicolumn{7}{|c|}{ haematocrit value \% } \\
\hline $21-24$ wks & $30.75 \pm 1.54 a$ & $25.50 \pm 1.26 b$ & $24.67 \pm 1.26 b$ & $25.20 \pm 1.38 b$ & $27.17 \pm 1.26 a$ & $23.67 \pm 1.26 b$ \\
\hline $25-28$ wks & $30.89 \pm 1.53 a$ & $26.80 \pm 1.19 a b$ & $25.30 \pm 1.25 b$ & $25.95 \pm 1.30 b$ & $26.19 \pm 1.27$ a & $25.47 \pm 1.18 b$ \\
\hline $29-32$ wks & $31.00 \pm 1.54 a$ & $27.00 \pm 1.38 a$ & $26.50 \pm 1.26 a b$ & $27.00 \pm 2.18 a$ & $25.67 \pm 1.26 b$ & $27.83 \pm 1.26 a$ \\
\hline \multicolumn{7}{|c|}{ Haemoglobin value (g/100ml) } \\
\hline $21-24$ wks & $12.38 \pm 0.57 a$ & $9.67 \pm 0.46 b$ & $9.33 \pm 0.46 b$ & $9.20 \pm 0.51 b$ & $10.67 \pm 0.46 a b$ & $8.75 \pm 0.46 b$ \\
\hline $29-32$ wks & $11.60 \pm 0.56 a$ & $10.39 \pm 0.49 a b$ & $9.40 \pm 0.44 b$ & $8.70 \pm 0.72 b$ & $10.19 \pm 0.41 a b$ & $9.19 \pm 0.42 b$ \\
\hline $25-28$ wks & $10.75 \pm 0.56 a b$ & $11.10 \pm 0.51 a$ & $9.42 \pm 0.46 b$ & $8.50 \pm 0.80 b$ & $9.83 \pm 0.46 b$ & $9.67 \pm 0.46 b$ \\
\hline \multicolumn{7}{|c|}{ Cholesterol, mg/dl } \\
\hline $21-24$ wks & $196.92 \pm 8.50 a$ & $193.65 \pm 8.50 a$ & $212.05 \pm 8.50 a$ & $183.90 \pm 8.50 b$ & $184.45 \pm 8.50 b$ & $182.83 \pm 8.50 b$ \\
\hline $25-28$ wks & $193.76 \pm 8.30 a$ & $182.33 \pm 8.52 b$ & $182.12 \pm 8.40 b$ & $182.60 \pm 8.49 b$ & $170.15 \pm 8.40 b$ & $178.15 \pm 8.51 b$ \\
\hline $29-32$ wks & $192.03 \pm 8.50 a$ & $174.83 \pm 8.50 b$ & $158.53 \pm 8.50 c$ & $183.72 \pm 8.50 a$ & $168.72 \pm 8.50 b$ & $172.82 \pm 8.50 b$ \\
\hline
\end{tabular}

a and b: Means having different superscripts within each row are significantly different $(\mathbf{P}<\mathbf{0 . 0 5})$

Fayoum J. Agric. Res. \& Dev., Vol.22, No.2, July, 2008 
In conclusion, Brown Bovans had significantly better FC and economic efficiency than White Bovans. The group fed the growth promoter CYC-100 had significantly higher FI and poorer FC and economical efficiency than those fed the control diet and hens fed the MY treatment had higher economic efficiency of 0.777 than the other treatments. Period of production significantly influenced either FI or FC $(\mathrm{P} \leq 0.05)$. Hens had the lowest FI of $95.22 \mathrm{~g}$ during the period from 21-24 weeks of age, however those fed both growth promoters were insignificantly differed than each other. Layers had the best FC of $2.02 \mathrm{~g}$ feed/g egg mass during the period from 29-32weeks of age whereas the worst FC was $15.14 \mathrm{~g}$ feed/g egg mass during the early period of production from 21-24 weeks of age. The White Bovans had significantly higher egg production \% with lower EW than the Brown Bovans. However, strain insignificantly affected EW. It can be seen that growth promoters (CYC-100 and MY) improved EP\% as compared with the control.

\section{REFERENCES}

Abd El- Rahman, S.A. (1993). Effect of dietary protein level with antibiotic or probiotic supplementation on performance of laying hens. Egypt. Poult. Sci. 13: 501- 519.

Abdulrahim, S.M., M.S.Y. Haddadin, E.A.R. Hashlamoun and R.K. Robinson (1996). The influence of lactobacillus acidophilus and bacitracin on layer performance of chickens and cholesterol content of plasma and egg yolk. Br. Poult. Sci. 37: 341-346.

Balevi, T., U.S. Ucan, B. Coskun, V. Kurtoglu and I.S. Cetingul (2001). Effect of dietary probiotic on performance and humoral immune response in layer hens. Br. Poult. Sci.. 42: 456- 461.

Duncan, D.B. (1955). Multiple Range and Multiple F tests. Biometrics, 11:1 42.

Ezzat, I.E., A.A. Ghazalah., S.A. Arafa, and A. E. Abdela (1988). The effect of graded levels of lactobacillus and low dosage Gamma irradiation on egg production. J. Agric Sci., Mansora Univ., 13 (3): 1037-1046.

Fuller, R. (1989). Probiotics in man and animals. J. Appl. Bacter. 66: 365-378.

Fuller, R. (1997). The importance of lactobacilli in maintaining normal microbial balance. Br. Poult. Sci. 38: 85- 94.

Ghazalah, A.A., and F.A.A. Ibrahim (1998). Effects of dietary supplementation of butter milk as natural probiotic on the performance of growing and laying Japanese quails. Egypt. Poult. Sci. 18 (1): 6180.

Haddadin, M.S.Y., S.M. Abdulrhim, E.A.R. Hashlamoun and R.K. Robinson (1996). The effect of lactobacillus acidophilus on the production and chemical composition of hen's eggs. Poult. Sci. 75: 491 $-494$.

Hamid, A., F. Zkham, A. Munid and M.A. Qadeer (1994). Probiotic in poultry productien. Bangladesh J. Scientific and Industrial Researcher 29 (4): 1-12.

Heady, E.O. and H.R. Jensen (1954). Farm Management Economics Prentice Hall, Inc., Englewood Cliffs, N.J. USA.

Fayoum J. Agric. Res. \& Dev., Vol.22, No.2, July, 2008 
Jin, L.Z., Y.W. Ho., N. Abdullah and S. Jalaludin (1997). Probiotics in poultry: mode of action. World's Poult. Sci. J. 53:351-367.

Katz, R., and E. Demain (1977). Peptide antibiotics of Bacillus. Bacterial Rev. 41: 449-474.

Kaya, S., Z. Erdogan and S. Erdogan (2003). Effect of different dietary levels of Yucca Schidigera powder on the performance, blood parameters and egg yolk cholesterol of laying quails. J. Vet. Med. vol. 50 (1): 14-17.

Kucukersan, K., S. Kucukersan and E. Goncuoglu (2002). The effects of probiotics and enzyme supplementation on egg production and quality. Ind. Vet. J. 79: $805-809$.

Makaren, A. (1974). Hemoglobin, myoglobins and haptoglobins. In: Clinical Chemistry. $2^{\text {nd }}$ Ed., Edited by Henry, R. G., D. C. Cannon and G. W. Winkelman, Harper, Row, Publishers, Hagerstown, Maryland, New York, USE, 1131.

Miles, R.D., H.R Wilson., A.S. Arafais, E.C. Coligado and D.R. Ingram. (1981). The performance of Bobwhite quail fed diets containing lactobacilli. Poult. Sci. 60:894- 896.

Mohan, B., R. Kadirvel, M. Bhaskaran and A. Natarajan (1995). Effect of probiotic supplementation on serum/ yolk cholesterol and on egg shell thickness in layers. Br. Poult. Sci.. 36: 799- 803.

Nahashon, S.N., H.S. Nakaue and L.W. Mirosh (1996a). Nutrient retention and production parameters of Single Comb White Leghorn layers fed diets with varying crude protein levels and supplemented with directfed microbials. Animal Feed Science and Technology 57:17- 26.

Nahashon, S.N., H.S. Nakaue and L.W. Mirosh (1996b). Performance of Single Comb White Leghorn layers fed a diet with a live microbial during the growth and egg laying phases. Animal Feed Science and Technology. 57: $25-38$.

Nahashon, S.N., H.S. Nakaue and L.W. Mirosh (1994a). Phytase activity, phosphorus and calcium retention, and performance of Single Comb White Leghorn layers fed diets containing two levels of available phosphorus and supplemented with direct-fed microbials. Poult. Sci. 73: $1552-1562$.

Nahashon, S.N., H.S. Nakaue and L.W. Mirosh (1994b). Production variable and nutrient retention in single comb white leghorn laying pullets fed diets supplemented with direct fed Microbials. Poult. Sci. 73: 1699 1711.

Nahashon, S.N., H.S. Nakaue and L.W. Mirosh (1992). Effect of direct-fed microbials on nutrient retention and production parameters of laying poullets. Poult. Sci. 71 (Suppl. 1): 111.

Nahashon, S.N., H.S. Nakaue and L.W. Mirosh (1993). Effect of direct-fed microbials on retention and production parameters of Single Comb White Leghorn pullets. Poult. Sci. 72 (Suppl.2): 87

Nelson, C.R. and S.F. Gilliand (1984). Cholesterol uptake by lactobacillus acidophilus. J. Dairy Sci. 67. (Supplement).

NRC (1994). Nutrient Requirements of Poultry. $9^{\text {th }}$ ed., National Academy of Science, National Research Council. Washington, D.C., USA.

Fayoum J. Agric. Res. \& Dev., Vol.22, No.2, July, 2008 
EFFECT OF SOME GROWTH PROMOTERS ON PERFORMANCE .. 256

Osman, M. (2003). The influence of probiotics inclusion on the productive performance of commercial layers. Egypt. Poult. Sci. 23 (11): 283 297.

Panda, A.K., M.R. Reddy., S.V. Rama Rao and N.K. Praharaj (2003). Production performance, serum/ yolk cholesterol and immune competence of White leghorn layers as influenced by dietary supplementation with probiotic. Trop Anim. Health, Feb, 35 (1): 85-94.

Panda, A.K., S.V. Rama Rao, M.R. Reddy and N.K. Praharaj (2000). Response of White Leghorn layers to diets fed with various levels of probiotic.. Ind. J. Anim. Sci. 70 (3): 311- 312.

Panda, A.K., S.V. Rama Rao, M.R. Reddy and N.K. Praharaj (2000). Response of White Leghorn layers to diet fed with various levels of probiotic.. Ind. J. Anim. Sci. 70 (3): 311- 312.

Rao, D.R., C.B. Chawan and S.R. Pulusani (1981). Influence of milk thermophilus milk on plasma cholesterol levels and hepatic cholesteogenesis. J. Food Sci. 46: 1339-1341.

Richmond, W. (1973). Preparation and properties of cholesterol oxidase from Nocarbia sp. and its application to the enzymatic assay of total cholesterol in serum. Clin Chem. $19: 1350-1356$.

SAS. (1982). SAS User's Guide. Statisties. SAS Institute Inc. Cary. N.C.

Savage, D.C., R. Dubos and R.W. Scheadler (1986). The gastrointestinal epithelium and its autochthonous flora. J. Exp. Med. 127: 67- 76.

Siam, S.S., S.A. Riad, F. R. Mohamed, and A.K. Alm eldein (2004). Influence of using two different levels of probiotics on egg performance, blood and yolk cholesterol of laying hens. Egypt. Poult. Sci. (24): 267-294.

Steel, R.G.D. and J.H. Torrie (1980). Principles and Procedures of Statistics. $2^{\text {nd }}$. ed. Mc Graw Hill Book Comp. New York.

Tortuero, F. and E. Fernandez (1995). Effect of inclusion of microbial cultures in barley- based diets fed to laying hens. Animal Feed Science and Technology. 53: $255-265$.

Yousefi, M. and K. Karoodi (2007). Effect of probiotic Thepax and Saccharomyces cerevisiae supplementation on performance and egg quality of laying hens. Int. J. Poult. Sci., 6 (1): 52-54.

Fayoum J. Agric. Res. \& Dev., Vol.22, No.2, July, 2008 


$$
\text { تأثير بعض منشطات النمو على الأداء الانتاجى لانتاج البيض لاجاج الباجي }
$$

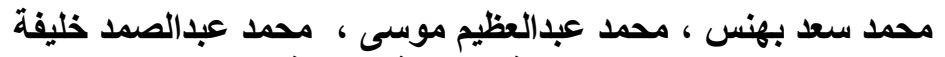

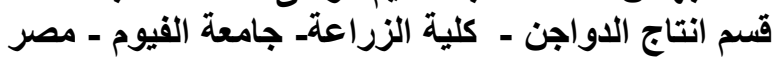

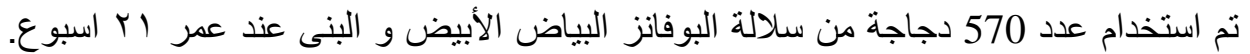

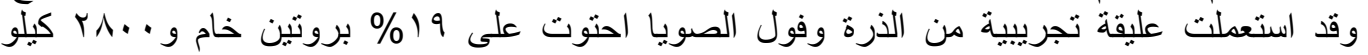

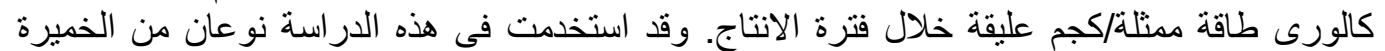

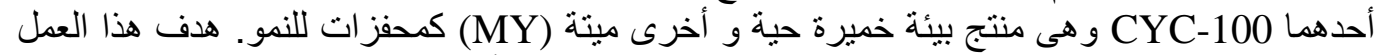

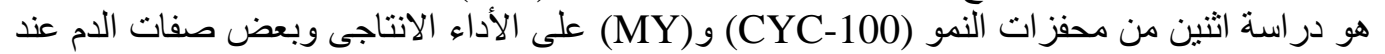

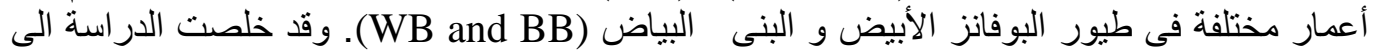

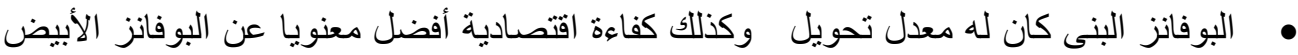

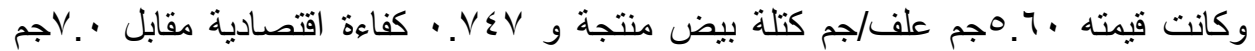

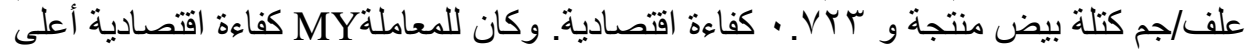

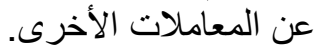

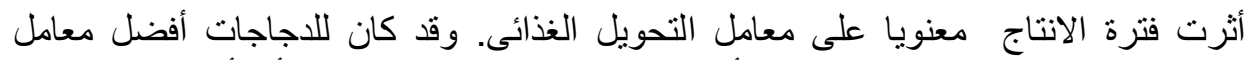

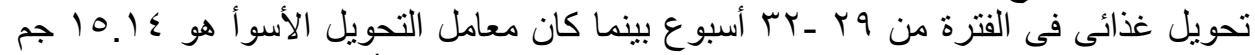

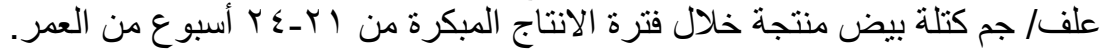

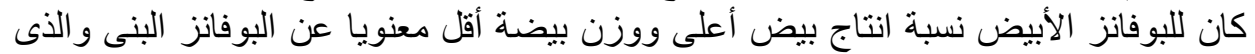

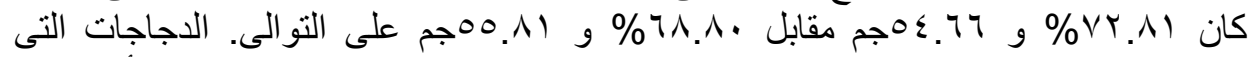
تغذت على كل من و

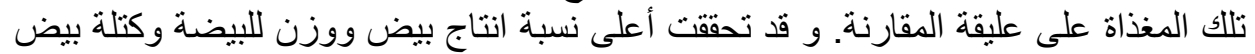

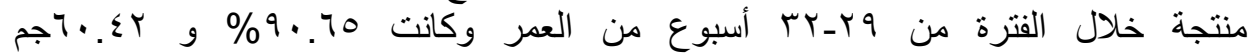

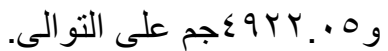

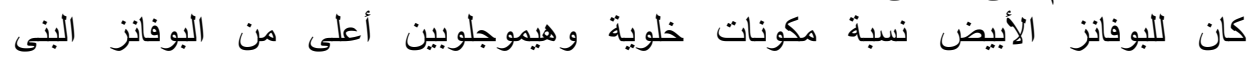
) (

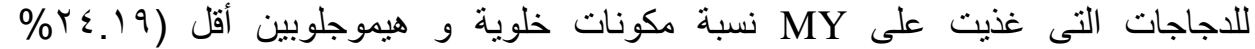

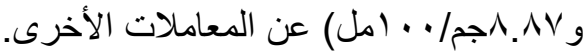
العلائق المدعمة بـ CYC-100 and MY كان بها محتوى كوليسترول أقل عن المغذاة على المئ عليقة المقارنة.

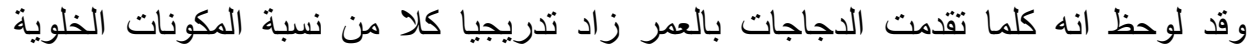

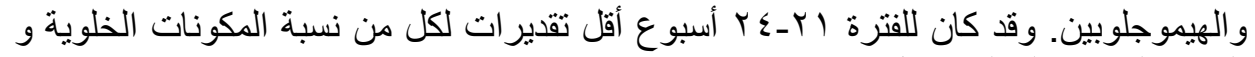
الهيمو جلو بين و الكوليسترول. ولئل 